\title{
Conspiracy Theories and the Conventional Wisdom \\ Revisited $^{1}$
}

(C)

\section{Charles Pigden}

Forthcoming in Olli Loukola ed Secrets and Conspiracies, Rodopi. References please to the published version when it appears.

\begin{abstract}
Conspiracy theories should be neither believed nor investigated - that is the conventional wisdom. I argue that it is sometimes permissible both to investigate and to believe. Hence this is a dispute in the ethics of belief. I defend epistemic 'oughts' which apply in the first instance to belief-forming strategies which are partly under our control. But the belief-forming strategy of not believing conspiracy theories would be a political disaster and the epistemic equivalent of self-mutilation. I discuss several variations of this strategy, interpreting 'conspiracy theory' in different ways but I conclude that on all these readings, the conventional wisdom is deeply unwise.
\end{abstract}

\section{1) Political Ploys and Epistemic Principles}

The conventional wisdom about conspiracy theories is that they ought not to be believed. To call something 'a conspiracy theory' is to suggest that it is intellectually suspect; to call someone 'a conspiracy theorist' is to suggest that he or she is irrational, paranoid or perverse ${ }^{2}$. Often the suggestion seems to be that conspiracy theories are not just suspect, but utterly unbelievable, too silly to deserve the effort of a serious refutation. It is a common ploy on the part of politicians to dismiss critical allegations by describing them as conspiracy theories, a tactic of which Tony Blair was a master. The idea that the invasion of Iraq was 'all about oil' or that (as leaked memo seemed to show) President Bush had seriously proposed bombing al-Jazeera's headquarters in Doha were both 'conspiracy theories' and therefore not worth discussing ${ }^{3}$. Blair's comments on the bombing memo were particularly eloquent. "Look, there's a limit to what I can say - it's all sub judice, ... But honestly, I mean, conspiracy theories..."4. (The matter was 'sub judice' because the Attorney General, presumably at Blair's behest, was prosecuting the people who had leaked the

\footnotetext{
${ }^{1}$ This is a revised and expanded version of my paper 'Conspiracy Theories and the Conventional Wisdom' (2007) Episteme: A Journal of social Epistemology, 4;2, pp 193-204.

${ }^{2}$ For a detailed study of this polemical tactic see Husting, and Orr, (2007).

${ }^{3}$ See Coady (2006b), p. 115 for details. Blair continues to use 'conspiracy theory' of as a blanket term of denigration for theories that he does not like (especially those that challenge his shining moral credentials) See his in his autobiography, A Journey, Blair (2010), pp 381, 397, 408,454 and 459.

${ }^{4}$ The Daily Telegraph, 28/11/2005
} 
memo.) Blair's tactic of using 'conspiracy theory' to dismiss ideas that he did not want to discuss would only have been honest $t^{5}$ if he had genuinely supposed that conspiracy theories as such ought not to be believed (except perhaps if proven up to the hilt) and it would only have been respectable if Blair's apparent belief had been correct. Thus the tactic relies on the epistemic principle that, in general, conspiracy theories ought not to be believed (that is, that it is irrational to believe them), and indeed that they are mostly so irrational that they ought not to be discussed, except perhaps as symptoms of some ideological malaise.

Thus the conventional wisdom seems to be that we have an epistemic duty not to believe (or investigate) conspiracy theories, a duty which conspiracy theorists conspicuously neglect. I shall be denying that we have any such duty, and shall be arguing on the contrary that we are rationally entitled to believe in conspiracy theories, if that is what the evidence suggests. Some conspiracy theories are sensible and some are silly, but if they are silly this is not because they are conspiracy theories but because they suffer from some specific defect - for instance, that the conspiracies they postulate are impossible or far-fetched. But conspiracy theories as such are not epistemologically unclean, and it is often permissible - even obligatory - to believe them. For sometimes the case for conspiracy can be rationally overwhelming, 'proved beyond reasonable doubt', and even when it is not, belief in a conspiracy is often a rational option. Thus my dispute with the conventional wisdom is a debate about the ethics of belief. It is common ground in this debate that it makes sense to say that we ought to believe something (that believing it is right or rationally required), or that we ought not to believe it (that believing it is wrong, a sort of crime against reason). It also makes sense to say that we are entitled to believe something (since believing it is permissible). Furthermore, all these claims can aspire to truth though whether they are actually true is another matter. Thus Tony Blair's rhetoric

\footnotetext{
${ }^{5}$ I must admit to doubts about Blair's intellectual honesty. The second of these two allegations - that Bush seriously discussed the bombing of al-Jazeera, a suggestion that Blair apparently opposed - was born out by a leaked memo for which the leaker, David Keogh, has been prosecuted. It may well be that Blair wanted to issue a non-denying denial; to dismiss the allegation without actually making the lying claim that the discussion had never taken place. Thus he claimed that the allegation was a conspiracy theory - which I suppose it is, though the conspiracy in question was not into put into effect - and therefore that it should be dismissed even though he was well aware that it was true. But in that case he cannot have consistently supposed that conspiracy theories as such are unbelievable, the kind of thing that rationally ought not to be believed, since the conspiracy theory he was talking about was not only true but provable on the basis of documentary evidence. Thus he may have avoided a direct lie but only by implying belief in an epistemic principle that he knew, or could have known, to be false. Interestingly, Blair simply burkes the issue in his autobiography. There is no reference to the Mirror story summarizing the leaked memo, no mention of the accusation that his friend and ally was a man whose love of freedom was such that he was willing to murder people for daring to publish stories that he did not like, and no reference to the leaker (David Keogh) who was sent to jail for revealing what a monster Blair had been consorting with.
} 
carries some fairly heavy philosophical baggage. The point of dismissing the allegation that Bush considered bombing al-Jazeera as a 'conspiracy theory' was to suggest that we are under some sort of intellectual obligation not to believe it. But we can't be obliged not to believe conspiracy theories unless we have epistemic obligations.

However, although the idea of epistemic duties may be common ground in the context of the current dispute, it is, in fact, highly debatable. The difficulty derives from the Ought-Implies-Can principle (which presumably applies to the ethics of belief) combined with the idea that belief is not a voluntary business. The claim is that we cannot decide what to believe or disbelieve. When faced with certain considerations we are either moved by the evidence or we are not. Decision and choice do not enter into it. Even with practice we cannot decide, like the White Queen in Alice $^{6}$, to believe six impossible things - or even six possible things - before breakfast. And it is equally impossible to decide not to believe six things before breakfast, whether the things in question are possible or not. But if Bloggs cannot help believing that agents of the Bush family detonated the Twin Towers, then it is not only pointless but actually false to suggest that he ought to believe otherwise. For you can't have an obligation to do what you cannot do and ex hyothesi, Bloggs in incapable of disbelieving that it was Bush family agents that did the deed. Thus the whole idea of an epistemic ethic is fundamentally cock-eyed, since it presupposes (wrongly) that we can control our beliefs.

This conclusion depends on two premises: Ought-Implies-Can and the idea that we cannot choose to believe. I am inclined to dispute them both. OughtImplies-Can is not a logical thesis but a plausible ethical principle that holds (with restrictions) in some systems of ethics but not in others ${ }^{7}$. It is not clear that it is has to be incorporated into a plausible ethics of belief. And though we cannot bring ourselves to believe just anything it seems to me that within limits we can often decide where to place our epistemic bets. The same thing goes for the two kinds of disbelief (both not believing and believing that not). We can sometimes choose not to believe either by ceasing to believe in a proposition or by deciding to believe its negation. Those who think otherwise sometimes counter this suggestion by

\footnotetext{
${ }^{6}$ Carrol , Lewis (1871) Alice Through the Looking-Glass ch. 5: Alice laughed. 'There's no use trying,' she said: 'one can't believe impossible things.' 'I daresay you haven't had much practice,' said the Queen. 'When I was your age, I always did it for half-an-hour a day. Why, sometimes I've believed as many as six impossible things before breakfast'.

${ }^{7}$ See Pigden, (1990) and Pigden (2010).
} 
producing a random thesis and challenging you to believe it ${ }^{8}$. When you can't, they claim victory, and if you insist that you can, their tendency is to scoff. But just because we cannot always choose to believe, it does not follow that we can never choose to believe, and where choice is a possibility, 'oughts' are not excluded. However, though my first instinct is to challenge the premises, there is a better way of countering the argument that an epistemic ethic is a non-starter since we cannot choose to believe. For though we cannot always choose to believe, we can often choose which belief-forming strategy to adopt. This was Pascal's response to the freethinking gamblers who agreed that it would be good idea to believe in God (since according to the Wager Argument, this would be the best bet), but who could not quite bring themselves to do so. Perhaps you cannot choose to believe in God, Pascal concedes, but you can choose to adopt a belief-forming strategy which is likely to bring about the desired result. If you go to church, hear masses and generally lead the life of a religious believer, the chances are that belief will follow - you will 'make yourself stupid' ${ }^{\prime}$. Other belief-forming strategies are less mind-numbing. For example, you can cultivate the habit of thinking up objections to claims that you would like to be true - a strategy that will make you less likely to confuse wishes with facts (a vice to which philosophers and politicians are peculiarly prone). Thus the best way to save an epistemic ethic is to take the deontic operators as applying, in the first instance, to belief-forming strategies rather than beliefs. What the conventional wisdom demands is not so much that we disbelieve this conspiracy theory or that, but that we adopt the intellectual habit of discounting, dismissing and disbelieving conspiracy theories generally (indeed of 'dissing' them altogether). Rather than running around trying to evaluate the evidence, the sensible strategy when confronted with conspiracy theories is to shut our eyes to their intellectual charms. I advocate the alternative strategy, that of not dismissing conspiracy theories out of hand, simply because they are conspiracy theories, but of being prepared to investigate them and even to believe them if that is what the evidence indicates. Perhaps some conspiracy theories, are too way out to be worthy of investigation, but this is not because they are conspiracy theories but because the specific conspiracies that they postulate are absurd or improbable. For conspiracy theories as such are no less worthy of belief than theories of other kinds. Thus the dispute is primarily a debate about which belief-forming strategy to adopt rather than

\footnotetext{
${ }^{8}$ My colleague Alan Musgrave deploys this tactic in Musgrave (2010) p. 12.

${ }^{9}$ Quoted and discussed in Mackie, J.L (1981) pp. 200-203.
} 
which claims to believe. Hence we can discuss the question sensibly as in issue in the ethics of belief, even if we grant, what seems to me to be false, that we cannot choose to believe. For even if our beliefs are not directly under our control, our belief-forming strategies often are.

But what is the status of these epistemic 'oughts'? Are they categorical imperatives (Requirements of Reason) or hypothetical imperatives pointing out the means to achieve some widely shared but intellectually optional end, such as achieving an adequate understanding of the world? I incline to the latter view, though I suspect it would be a difficult business to specify the precise ends to which a respectable epistemic 'ought' prescribes the means. But whatever the precise status of epistemic 'oughts', the claim that we rationally ought to adopt a belief-forming strategy (such as not believing in or not enquiring into conspiracy theories), would appear to presuppose that the strategy in question is conducive to truth and the avoidance of error, at least under a wide range of circumstances. Thus the rationale for the strategy of conspiratorial skepticism is that it is more likely to get it right or less likely to get it wrong than its epistemic rivals. It rests on the presumption that conspiracy theories are unlikely to be true, in fact so unlikely that they are generally not worth discussing. Indeed, it requires something stronger than the simple assumption that conspiracy theories, as such, are unlikely to be true. The space of possible theories is large; the space of true theories, small. But it would be silly to conclude from this that we ought to abstain from theorizing to avoid the risk of error (the official position of the ancient Skeptics). The fact that theories in general are more likely to be false than true does not mean that we should give up theorizing or enquiring into theories. By the same token, the fact that conspiracy theories are more likely to be false than true does not entail that we should give up conspiracy theorizing or enquiring into conspiracy theories. For that to be a sensible strategy we would have to suppose that conspiracy theories are much more likely to be false than their non-conspiratorial rivals. And since he seems to think that we ought not to believe or enquire into conspiracy theories, that is, presumably, the opinion of Tony Blair and the pundits of the conventional wisdom who seem to agree with him.

\section{2) What is a Conspiracy Theory?}

So what is a conspiracy theory? In my book a conspiracy theory is simply a theory which posits a conspiracy - that is a secret plan on the part of some group to influence events by partly secret means. The conspiracy does not have to be 
successful for the theory to count as a conspiracy theory nor do the plans of the conspirators have to stay secret. A conspiracy does not cease to be a conspiracy if it fails to achieve its objectives. Hence, a theory which postulates a conspiracy does not cease to be a conspiracy theory if the conspiracy that it postulates has failed to achieve its alleged objectives. If we explain some event as due, in part, to a conspiracy, we do not have to assume that the plotters conspired to bring about that very event since the best-laid plans of mice and conspirators gang aft agley. The conspiracy to burglarize the Democratic Party offices in the Watergate Building was a conspiracy to burglarize the Democratic Party offices and get away with it, not a conspiracy to burglarize the Democratic Party offices and get caught. The idea was to help the President, not to bring about his downfall. The idea of the cover-up was to conceal the White House's complicity in the affair not to involve the President in a criminal conspiracy that would ultimately force him to resign just one jump ahead of a House vote for impeachment. Thus the cock-up theory of history - the idea that much of history is to be explained in terms of cock-ups of some kind - is not incompatible with the thesis that some historical events are also due to conspiracies. If you are not trying to do something you can't cock it up, and sometimes the schemes that historical actors manage to cock up have been planned and partly executed in secret. Failed conspiracies have had a major impact on history: witness not only Watergate but the disastrous attempt by the Communist old guard to halt or reverse Gorbachev's reforms by kidnapping and coercing him, a conspiracy which led to the collapse of Communism, the very reverse of what the conspirators intended. Both Watergate and the Gorbachev kidnapping were cock-ups on a truly epic scale but they were both also due to conspiracies. (See Pigden (1995/2006a) where this point is argued at length.)

Although a conspiracy theory requires a secret plan, the alleged plan does not have to stay secret for the theory to count as a conspiracy theory. Since a conspiracy does not cease to be a conspiracy if the secret plot subsequently becomes public, a conspiracy theory does not cease to be a conspiracy theory if what were once secret plans have ceased to be secret. When Brutus and Cassius plotted to murder Caesar, they did so in secret since a public plot would have been foiled. But once the deed was done, they gloried very publicly in the fulfillment of their hitherto secret plans:

Brutus: Stoop, Romans, stoop,

And let us bathe our hands in Caesar's blood 
Up to the elbows, and besmear our swords:

Then walk we forth, even to the market-place,

And, waving our red weapons o'er our heads,

Let's all cry ‘Peace, freedom and liberty! ${ }^{10}$

This rather gory piece of political theatre did not falsify the claim that Brutus, Cassius and their confederates had conspired to stab Caesar. Hence the theory that they had done so did not cease to be a conspiracy theory once it had been bloodily and publicly confirmed.

Finally, a theory, in my book, is a more or less organized body of propositions designed to explain some alleged facts. Theories can be true or false, sensible or silly, and when they are sufficiently well-confirmed, they can rise to the dignity of knowledge. Indeed in common parlance we can even talk about proving theories, though this is a usage that would shock true Popperians. Thus to call something a theory is not to suggest that it is tentative, speculative or unproven, (though many theories are, of course, tentative, speculative or unproven). Hence to say that a theory has been proven is not to suggest that it has ceased to be a theory. True theories and false theories, well-confirmed theories and decisively refuted theories are all of them, nonetheless theories.

So much for my definition, which (please note) does not, by itself entail that conspiracy theories either are or are not irrational. But once this definition is combined with some obvious facts, we arrive at some interesting conclusions.

\section{3) If You Are Not a Conspiracy Theorist, Then You Are an Idiot}

If a conspiracy theory is simply a theory that posits a conspiracy, then every politically and historically literate person is a big-time conspiracy theorist, since every such person subscribes to a vast range of conspiracy theories. That is, historically literate people believe organized bodies of propositions that explain alleged facts by positing conspiracies. For there are many facts which admit of no non-conspiratorial explanation and many conspiracy theories that are sufficiently well-established to qualify as knowledge. This affords us a deductive argument for the claim that it is not irrational to believe in some conspiracy theories, an argument that proceeds from premises that it is difficult to rationally deny:

\footnotetext{
${ }^{10}$ Shakespeare, Julius Caesar, III.i. Shakespeare is dramatizing real-life events.
} 


\section{Argument A}

a) A conspiracy theory is a theory that explains some event or events as due in part to a conspiracy, that is, to a secret plan to influence events by partly secret means.

b) Every historically and politically literate person employs the strategy of sometimes believing (and sometimes being prepared to believe) conspiracy theories.

c) It is not irrational to employ a belief-forming strategy that every historically and politically literate person employs.

Therefore

d) It is not irrational to employ the strategy of sometimes believing (and sometimes being prepared to believe) conspiracy theories.

Premise a) is simply a neutral non-question-begging definition of a conspiracy theory - that is, a definition that has not been carefully rigged so as to make conspiracy theories come out as irrational. I defer the defense of premise b) to $\S 4$, but it depends upon the fairly obvious fact that both history and the nightly news are choc-a-bloc with conspiracies, many of them proved beyond all reasonable doubt. Thus anyone who does not believe that history and the nightly news have been systematically faked, believes in a huge number of conspiracy theories and is therefore a big-time conspiracy theorist. And if you do believe that history and the nightly news have been systematically faked, this presupposes a massive and malevolent conspiracy to deceive us all. Hence my proof that you, dear Reader, are conspiracy theorist, whether you realize it or not:

\section{Argument B}

Premise I: Unless you believe that the reports of history books and the nightly news are largely false, you are a conspiracy theorist (since history and the nightly news are choc-a-bloc-with conspiracies).

Premise II: If you do believe that the reports of history books and the nightly news are largely false, you are a conspiracy theorist (since your presumably believe that somebody has conspired to fake them). Conclusion: You are a conspiracy theorist ${ }^{11}$.

\footnotetext{
${ }^{11}$ See Coady (2007) p. 193 who is stating a bit more formally an argument that I develop in Pigden (2006b)
} 
The only people not impaled on the horns of this dilemma are idiots in the Greek sense of the word - people who take so slight an interest in public affairs that they have no opinion as to whether history and the nightly news have been systematically falsified or not. Hence my subheading: if you are not a conspiracy theorist, then you are an idiot. Of course you can be a conspiracy theorist and still be an idiot in either the Greek or the modern senses of the word, but the only way to avoid being a conspiracy theorist of some kind is to wrap yourself in a such thick shroud of ignorance and insensibility, as to render yourself incapable of political thought or action. At any rate, my dilemma vindicates premise b) of Argument A. Every historically and politically literate person believes and is prepared to believe some conspiracy theories, since both history and the nightly news present many conspiracy theories as facts and others as reasonable hypotheses. You can't be a politically or historically literate person unless you think that although history and the nightly news may have been distorted, they have not been systematically faked, that is, that they are reasonably reliable. So every historically and politically literate person believes that some of the conspiracies reported by history and the nightly news are real, and thus that the corresponding conspiracy theories are true. It is therefore a condition of being a politically and historically literate person that you accept some conspiracy theories. This vindicates Premise b) of Argument A, namely that every historically and politically literate person employs the strategy of sometimes believing (and sometimes being prepared to believe) conspiracy theories of some kind.

What about Premise c) - that it is not irrational to employ a belief-forming strategy that every historically and politically literate person employs? It seems to me that this is difficult to deny. No doubt there are some strategies employed by many historically and politically literate people that are genuinely irrational. But though it is possible for a strategy employed by many historically and politically literate people to be irrational, it is surely absurd to suppose that a strategy that they all employ (and must employ to retain their titles to historical and political literacy) is an irrational strategy. Thus premises a), b) and c) deliver the conclusion d) - that it is not irrational to employ the strategy of sometimes believing (and sometimes being prepared to believe) conspiracy theories.

Let me stress again that Argument A is deductively valid. If the premises are true then the conclusion is true too. So if you reject the conclusion as false you must 
reject one of the premises. But b) and c) seem pretty safe. Given my definition of a conspiracy theory, history and the nightly news are both replete with conspiracy theories. Thus you can only avoid being a conspiracy theorist by either systematically disbelieving both history and the nightly news or by ignoring them altogether (and thereby lapsing into political idiocy). Neither of these is an option for the historically and politically literate person, hence all historically politically and literate people are conspiracy theorists. To suppose that c) is false is to suppose there are things which every historically and politically literate person does which no rational person ought to do, that is that every historically and politically literate person is irrational. I take a dim view of our intellectual elites, but even I don't suppose that irrationality is as quite as ubiquitous as that! This means that the only premise that is at all problematic is premise a) which simply defines a conspiracy theory as a theory which posits a conspiracy. I have already argued for this definition in $\S 2$ and I shall defend it further in $\$ \S 5$ and 6 . All I shall say now is that even those who employ 'conspiracy theory' as a term of intellectual abuse often seem to be using this definition in practice. What is the criterion for a theory to count as a conspiracy theory according to politicians and polemicists such as Blair? Usually it is enough that it a theory that posits a conspiracy (though the pundits of the conventional wisdom tend only to apply the term to theories they find inconvenient). Thus we have a deductive argument from hard-to-deny premises to the conclusion that it is not irrational to adopt the strategy of sometimes believing in conspiracy theories. And this contradicts the conventional wisdom, which seems to suggest that it is.

Indeed we can go further. There is a deductive argument from premises that are likewise difficult to deny to a much stronger conclusion, namely that the opposite strategy, suggested (though not consistently followed) by the pundits of the conventional wisdom - the strategy of systematically doubting, disbelieving and refusing to investigate conspiracy theories simply because they are conspiracy theories - is, itself, irrational.

\section{Argument C}

a) Many conspiracy theories (as I have defined them) are not only true but importantly true (the kind of thing that the citizen of a democratic country needs to know about) [Premise to be established in $\S 4$.] 
b) The strategy of systematically doubting, disbelieving and refusing to investigate conspiracy theories simply because they are conspiracy theories would inhibit us from believing or investigating conspiracy theories. [Premise - an obvious point that needs no argument.]

c) Therefore the strategy of systematically doubting, disbelieving and refusing to investigate conspiracy theories simply because they are conspiracy theories would inhibit us from believing or investigating some theories that are not only true but importantly true. [From premises $a$ ) and $b$ )]

d) A belief-forming strategy that would inhibit us from believing or investigating theories that are not only true but importantly true is irrational. [Premise: I take it that some such principle as this would be part of any plausible ethics of belief.]

e) The belief-forming strategy of systematically doubting, disbelieving and refusing to investigate conspiracy theories simply because they are conspiracy theories is irrational. [From c) and d) resting on premises a) b) and d).]

This argument too is deductively valid: if the premises are true the conclusion must be true too. But the only controversial premise is premise a). Hence if premise a) is true, it is not just rational, on occasion, to investigate and believe in conspiracy theories - it is irrational to follow the opposite strategy, the strategy, recommended by the conventional wisdom, of systematically doubting, disbelieving and refusing to investigate theories which posit conspiracies. So is premise a) correct? Are there conspiracy theories that are not only true but importantly true? The answer is obviously yes.

\section{4) History is not Bunk}

It is difficult, if not impossible, to mount a coup without conspiring, a point that is evident to all. Hence anyone who believes there are such things as coups must subscribe to a set of conspiracy theories however vague. Although some assassinations are due to 'lone gunmen', many are group efforts, and the efforts of those groups are usually planned in secret. (Had the plans of Brutus and Cassius been public, Caesar could have avoided the Senate House or arrested the potential murderers before they struck.) Thus anyone who knows anything about the Ides of 
March or the assassinations of Arch-Duke Franz Ferdinand or Tsar Alexander II is bound to subscribe to a conspiracy theory, and hence to be a conspiracy theorist. But coups and assassinations are not even the half of it. Disappearances are usually conspiratorial affairs, since if you want to disappear someone, you had better not let them know when you are coming. Of course, it can add to the fun if you let your victims know, in a general way, that somebody is out to get them (and many goons indulge this pleasure with threatening phone calls and other such 'warnings'), but if you are a member of a goon squad it is good idea to conceal your identity as well as your precise plans. And if you are organizing a campaign of disappearances, it as well to keep your activities secret. After all, picking up your political opponents and having them jailed, tortured or executed is generally regarded as not quite nice, particularly on the part of Presidents and Prime Ministers. And you can never be quite sure that some tedious do-gooder from the International Criminal Court won't catch up with you in the end. Much the same considerations apply if you plan to clean up the city by butchering the local street kids, a strategy that has been pursued in the past in Guatemala ${ }^{12}$, Brazil ${ }^{13}$ and Honduras ${ }^{14}$. Indeed, mass killings generally are often planned and partly executed in secret, the Holocaust being the supreme example, though one might also cite Stalin's purges. It is strange to suppose the massacre of millions of people could be not only planned but largely executed in secret, but that is the way it was. Hannah Arendt, a Jewish activist with a passionate interest in politics, and as well informed as private person was likely to be, did not hear about 'Auschwitz' (by which, I presume she means the Nazi extermination program generally) until 1943, and did not regard it as a proven fact until six months later. $^{15}$ If, like Chiang Kai-shek in $1927^{16}$, you want to massacre your erstwhile Communist allies with the aid of the local gangsters, then it is best not to publicize your plans. If, like the 'Young Marshal', Zhang Xueliang, in X'ian 1937'17, you plan to kidnap the Head of State with a view to coercing him into changing his policy, you had better not let him know in advance, and the operation had better be begun in secret to maximize the chance of success. Even at the everyday level of democratic

\footnotetext{
${ }^{12}$ See Amnesty International

http:/ / www.amnesty.org/en/library/asset/ AMR34/024/1992/en/51979676-edc2-11dd-a95bfd9a617f028f/amr340241992en.html

${ }^{13}$ See Amnesty International

http: / / www.amnesty.org/en/library / asset/ АCT31/002/1992/en/1145109d-ed9d-11dd-9ad7350fb2522bdb/act310021992en.pdf

${ }^{14}$ http:/ / www.hrea.org/lists/child-rights/markup/msg00138.html

${ }^{15}$ See Arendt, Hannah 'What Remains? The Language Remains' in Baehr ed. (2000), p. 13.

${ }^{16}$ See Fenby (2003) ch. 9.

${ }^{17}$ See Fenby (2003) pp. 1-18.
} 
politics, conspiracies are not uncommon. If my party leader is trailing in the polls and I am planning a leadership 'spill', I had best not let her know until I have a substantial number of MPs behind me. There is usually a good deal of secret plotting and furtive feeling out of potential supporters before a leadership challenge erupts into the open. In many countries it is not unknown for politicians and state officials to take bribes and misappropriate pubic funds. For obvious reasons, these activities are usually planned and executed in secret. Thus if you believe in such things you must be a conspiracy theorist of sorts, even if you are hazy about the details. Even in the small change of commercial life, conspiracies abound, a point acknowledged by Adam Smith, whose belief in he invisible hand of the market did not entail skepticism abut the invisible hands of individual conspirators: 'People of the same trade seldom meet together, even for merriment and diversion, but the conversation ends in a conspiracy against the publick, or in some contrivance to raise prices ${ }^{\prime 18}$. 'Masters too sometimes enter into particular combinations to sink the wages of labour even below this [actual] rate. These are always conducted with the utmost silence and secrecy, till the moment of execution' ${ }^{19}$ But I need not belabor a point that I have argued at length elsewhere ${ }^{20}$. History and the nightly news (not to mention common sense) all tell the same tale - people often conspire. Hence there is no reason to think that theories which postulate conspiracies are much more likely to be false than theories which explain the same events without the aid of conspiracies. Indeed there are many events for which there is no sane non-conspiratorial explanation. The Young Marshal's men did not individually decide without prior consultation to kidnap Chiang that day at X'ian in 1937, and if Mary, Queen of Scots, did not conspire to murder Lord Darnley at Kirk o' Fields in 1567, then somebody else did.

This suggests three conclusions:

I) If conspiracy theories are theories which posit conspiracies, then the epistemic principle that, conspiracy theories as such ought not to be believed or even investigated is absurd. It only makes sense on the assumption that conspiracy theories are much more likely to be false

\footnotetext{
${ }^{18}$ Smith (1981) An Inquiry into the Causes of the Wealth of Nations, vol. 1, p. 135.

${ }^{19}$ Smith (1981) An Inquiry into the Causes of the Wealth of Nations, vol. 1, p.84

${ }^{20}$ See Coady ed. (2006) pp. 17-18, 34-38, 157-60 \& 161-162.
} 
than their non-conspiratorial rivals and this assumption is false. The ploy of dismissing critical allegations as conspiracy theories is not intellectually respectable, whatever the conventional wisdom may say.

If I manage to convince the learned and the semi-learned worlds of this (not just academics, but journalists and the punditocracy) I shall not have lived in vain. For the idea that conspiracy theories as such are intellectually suspect helps conspirators, quite literally, to get away with murder (of which killing people in an unjust war is an instance). If George Bush did seriously propose the bombing of al-Jazeera, then the former President of the United States is the kind of man who was prepared to murder journalists for putting out news stories that he happened to dislike. And if there is evidence of this, which apparently there is, then it ought to be investigated. An epistemic principle that can help shield a politician from such an investigation is not merely ridiculous (though it is, of course ridiculous) - it's a threat to the common weal.

But important as this is, there are more interesting points to note. Brian Keeley (1999) contends that certain sorts of conspiracy theories ought not to be believed, not just because they are unlikely, but because to believe them would be to commit a sort of epistemic suicide. Following C.A.J. Coady, he argues that much of what we know, we know on the basis of testimony. If testimony is not largely reliable then we know virtually nothing. To suppose that testimony is largely unreliable is to suppose that we know virtually nothing, and this is something that we rationally ought not to believe. He then goes on to claim that many conspiracy theories - at least many that are castigated as such - require such a large amount of lying by so many people that they call testimony itself into question. To believe them is to suppose that testimony is largely unreliable and this is something that we ought not to believe. Therefore there are many conspiracy theories that we ought not to believe and the conventional wisdom is not so silly after all.

This argument has two premises - a) the epistemic principle that we ought not to believe a thesis which requires such extensive lying as to call testimony into question, and b) the factual claim that many conspiracy theories require so much coordinated lying by so many people as to do precisely this. The first is dubious, the second false. But what I want to argue now is that the boot is on the other foot. 
There are better reasons of essentially the same kind for rejecting the epistemic principle that by and large we ought not believe or even investigate conspiracy theories.

II) History, as we know it, both from documentary evidence and the best historians, is choc-a-bloc with conspiracies. Thus if conspiracy theories are theories which posit conspiracies, then to accept the conventional wisdom and adopt the principle that we ought not believe or investigate conspiracy theories would lead to the conclusion that history is bunk, that much of what we thought we knew is not only unbelievable, but not worth investigating. Much of recorded history would dissolve into a blur of inexplicable events, indeed events we should not even try to explain. To adopt this principle would be to commit historical suicide or at least selfmutilation, to make large chunks of history unbelievable and hence unknowable, since knowledge requires belief. It would maim, if not destroy, history as an intellectual discipline. But it is not rational to adopt an epistemic principle with such catastrophic consequences. Therefore it is not rational to suppose that we should not believe or even investigate conspiracy theories.

Perhaps it is worth stressing just how catastrophic this principle would be, if consistently practiced. (In fact nobody does this - rather people like Blair apply it in a haphazard way when it happens to suit their political purposes.) We would be entitled to believe that large quantities of gunpowder were discovered in the cellars of parliament in 1605, but not that Guy Fawkes and his confederates put it there, for that would be a conspiracy theory. We could accept that Lord Darnley died, but not that anybody killed him, since all the available explanations are conspiracy theories. We could accept that the 'Rightist-Trotskyite Bloc' was put on trial in 1938, but we could not allow ourselves to believe that they were either guilty or innocent, since both beliefs entail a conspiracy. (If they were guilty then there was a treasonable conspiracy of spies and wreckers at the heart of the Soviet State. If they were innocent, there was a tyrannical conspiracy on the part of Stalin and others to fabricate the appearance of conspiracy.) We could notice that a lot of communists were massacred in China in 1927, but we could not rationally suppose that Chiang and his Green Gang associates had conspired to kill them, for that would be a 
conspiracy theory. We could accept that World War II took place, but not that the Nazis conspired to wage it since that would be a conspiracy theory. (Good news for some of the Nuremburg defendants!) We could accept that the Holocaust occurred but not that anyone, Hitler included, conspired to bring it about. Moreover we would not even be allowed to investigate these questions, since any answer we came up with would be something we were not entitled to believe. If the conventional wisdom is correct, and we ought not to believe conspiracy theories, then history is bunk, since it is largely unbelievable, the kind of thing that we are rationally required not to believe. But history is not bunk - much of it merits belief, and that includes the many conspiracy theories of which we have ample evidence. Thus the conventional wisdom is wrong and conspiracy theories need not be rejected simply because they are conspiracy theories ${ }^{21}$.

What about my third conclusion? This concerns political crimes and current events, the recent rather than the remote past.

III) Most political crimes - from disappearances and illegal bombing campaigns down to breaking peaceniks' noses or burglarizing the campaign headquarters of the opposition party ${ }^{22}$ - are the products of conspiracy. Thus if conspiracy theories are theories which posit conspiracies, then if we adopted the principle that we should not believe and should not investigate conspiracy theories, we could not hold anyone responsible for such crimes. For to do so would be to accept some conspiracy theory or other. This would be an epistemic disaster, since our understanding of the political scene would dissolve in a mist of skepticism broken by islands of obvious fact. (We could believe in the dead bodies but not that anyone had conspired to kill them; believe in

\footnotetext{
${ }^{21}$ Here's an exercise for the reader. Get a second-hand copy of Fenby (2003) or Chang and Halliday, (2005). Then cut out all the references to actions planned and partly executed in secret. My guess is that you would have, in effect, a much shorter book, and that the parts which remained would be disjointed and unintelligible. That would be the history of $20^{\text {th }}$ Century China without conspiracy.

${ }^{22}$ The Nixon administration was responsible for three of the above and probably connived at disappearances, at least in foreign parts (as Kissinger certainly did under Ford). But oddly enough, what brought the Nixon administration down was the Watergate Burglary and the ensuing cover-up, perhaps the least heinous of its many political crimes. For the illegal bombing campaign ('anything that flies, anything that moves'), see Shawcross (1986). For beating up peaceniks and burglarizing the opposition headquarters see Summers, (2000). On May $5^{\text {th }} 1971$, Nixon endorsed Haldeman's suggestion that they organize some 'thugs' from the Teamsters Union to 'beat the shit out of these people [the peaceniks] .. and smash some noses'. Abbie Hoffman's nose was duly smashed. See Summers (2000) pp. 356-357.
} 
the missing money, but not in the felonious theft.) And it would a political disaster, since it would confer immunity on political criminals of all sorts, from the perpetrators of genocide down to bribe-taking congressmen. (We could not punish people for crimes that we were not entitled to believe in or investigate.) Thus it would be both politically and epistemically irrational to adopt the strategy of not believing in and not investigating conspiracy theories. So the conventional wisdom is wrong, and it is not the case that we ought not to believe and ought not to investigate conspiracy theories. When it comes to conspiracy theories we are within our rights as rational beings not only to investigate them, but actually to believe in them, if that is what the evidence suggests.

Again it is worth stressing just how catastrophic the strategy of conspiratorial skepticism would be if, instead of using it from time to time to time to rubbish allegations that we find inconvenient, we actually used it consistently. To begin with the political world would be largely unintelligible. We would be officially debarred from understanding coups, or the crimes of terrorists as intentional actions, since in both cases the intentions behind the overt acts are formulated in secret. Hence they cannot be understood as intentional acts without resorting to conspiracy. We could all acknowledge that the bombs had gone off but we could not suppose that someone had planted them, since that would be a conspiracy theory. We could accept that two planes had hit the Twin Towers but we could not allow ourselves to suppose they had been hijacked and deliberately crashed, since that could not have happened without a conspiracy. The nightly news would be bobbing with islands of unintelligibility, since we would be officially debarred from understanding any action involving secret plans. (I defy anyone to make sense of recent events in Iraq without taking account of the orgy of plotting that undoubtedly goes on. Death squads don't advertise their plans, neither do guerillas, gangsters, terrorists or devious politicians.) We would be allowed to understand natural phenomena and open actions, openly arrived at. And we might even treat ourselves to unintended consequences provided these did not involve secret plotting. But we would be officially blind to covert actions and secret plans. This would not quite be epistemic suicide, since there are some events within the political sphere that we would be officially allowed to understand. But to adopt the strategy of conspiratorial 
skepticism would be the epistemic equivalent of self-mutilation and hence not a rational thing to do.

Epistemically disastrous as conspiratorial skepticism would be, its political consequences would be catastrophic. For when it comes to conspiracy we would be both officially blind and officially incurious. Under this regime, Woodward and Bernstein would not have been allowed to investigate Watergate, and even if they had, nobody would have been rationally entitled to believe their results. Nixon would have gotten away with his crimes. For if conspiracy theories were taboo, there could be no question of impeaching the President for 'high crimes and misdemeanors', since most of those high crimes and misdemeanors were planned and executed in secret. The career of an investigative journalist like Seymour Hersh would stand condemned as one long exercise in irrationality since investigative journalism largely consists of investigating conspiracies and exposing them to the public gaze. If it is irrational to check out conspiracy theories, then the investigative part is a crime against reason, and if it is irrational to believe them, then the journalistic part is a crime against reason too, since it often consists in writing up conspiracy theories so as to encourage belief in the reader.

The strategy of systematically disbelieving conspiracy theories would not just be bad for the democratic public - it would also be bad for historical agents. According to Jang and Halliday, in the last phases of the Chinese civil war, two of Chiang's leading generals, Hu Tsung-nan and Wei 'a Hundred Victories' Li-huang, were in fact Communist agents who betrayed their troops to the enemy ${ }^{23}$. Chiang made the mistake of trusting them (or at least of not distrusting them more than anyone else) but if the conspiracy skeptics were right this would have been the correct thing to do since to believe in their treachery would have been to buy in to a conspiracy theory. (The alternative non-conspiratorial theory would have been that their spectacular defeats were simply due to military incompetence, admittedly a common failing on the part Chiang's generals.) Machiavelli advises his prince 'not to be too concerned about conspiracies', but this is not because conspiracies are nonexistent or even rare (on the contrary 'experience demonstrates' that conspiracies are common) but because, if the prince is neither despised nor hated, they are unlikely to succeed. And of course the wise prince takes pains not be despised or hated ${ }^{24}$. A prince who systematically discounted conspiracy theories would be naked to the

\footnotetext{
${ }^{23}$ Chang and Halliday (2005), pp. 312-323

${ }^{24}$ Machiavelli (2005) The Prince, pp. 62-65.
} 
schemes of his conspiratorial enemies. Henry V committed no epistemic crime when he believed the conspiracy theory suggested by the Earl of March, and foiled Lord Cambridge's plans to murder him at Southampton in $1415^{25}$. Indeed it would have been disastrous to have done otherwise.

One of the biggest problems with human rights abuses is impunity. Because the goons and their masters can usually get away with murder or (or worse $\mathrm{e}^{26}$ ) they have no compelling reason to cease and desist. But since most human rights abuses are the products of conspiracy, if we adopted the strategy of neither investigating nor believing conspiracy theories, impunity would become rationally sacrosanct. We could not investigate human rights abuses since, for the most part, this involves investigating conspiracy theories, and even if we could, we could not condemn their perpetrators, since to do that we would have to accept a conspiracy theory. Conspiratorial skepticism would provide the torturers and killers with a charter of impunity since it would become an epistemic no-no to shine a light into the dark places where they commit their crimes. Terrorists too would be immune from investigation, let alone conviction, since their crimes are usually planned in secret.

More generally, it is a platitude of liberal democracy that the price of liberty is eternal vigilance. At least part of what this means is that we must beware of powerhungry politicians conspiring to deprive us of our liberties. But if we were not allowed to investigate conspiracy theories then our vigilance would be confined to the public actions of politicians rather than their secret plans. We would have become officially blind to some of the most serious threats to liberty. And even if we somehow discovered such a conspiracy we would not be allowed to act on that discovery, since we could not act on a theory we had debarred ourselves from believing. According to Edmund Burke, 'There is no safety for honest men except by believing all possible evil of evil men. ${ }^{27}$ But if the conventional wisdom is correct, we should not believe in the evil of evil men unless that evil is out in the open! Thus if you hate the freedoms of a democratic society, you should cultivate the opinion that conspiracy theories are unbelievable. Conversely, if you want to strike a blow

\footnotetext{
${ }^{25}$ See Shakespeare Henry V, II.ii and Mortimer (2010), p. 206. Shakespeare omits to mention that Henry was tipped off by the Earl of March, the principal beneficiary of the plot.

${ }^{26}$ For example disappearing pregnant women and allowing them to give birth in prison before murdering them (sometimes by tossing them out of planes over the Atlantic) and then adopting out their children to childless members of the Security Services - an Argentine specialty during the 'Dirty War'.

${ }^{27}$ Burke (1992), p. 33.
} 
for liberty (or if you want to be able to see the threats to liberty in order to be capable of striking a blow for it) this is a thesis you that should reject.

\section{5) What Then Does the Conspiracy-Skeptic Mean?}

If I am right, the conventional wisdom on conspiracy theories is not just misguided, but utterly absurd. For it implies an epistemic principle that flies in the face of history and would be politically catastrophic if put into practice. It would blind us to the machinations of torturers and scheming politicians, and would convert a large part of the political realm into a chaos of incoherent effects whose causes were beyond the reach of rational enquiry. But my conclusions only follow given an important proviso - that conspiracy theories are theories that posit conspiracies (which was why I was careful to put it into italics). This is the antecedent of theses I), II) and III) and a premise in Arguments A, B and C. But perhaps the pundits of the conventional wisdom mean something else by 'conspiracy theory' when they dismiss such theories as irrational? If he aspires to pragmatic consistency Tony Blair had better mean something else. For at the very period when he was dismissing conspiracy theories as not worth refuting, the foreign policy of the United Kingdom was officially based on not one but three distinct conspiracy theories (in the sense outlined above) one true, and two false:

i) That the events of $9 / 11$ were due, in part, to a conspiracy on the part of al-Qaeda (which was itself in league with the Taliban).

ii) That the regime of Saddam Hussein was in cahoots with al-Qaeda, making him in some sense an accessory to the events of $9 / 11^{28}$.

iii) That the regime of Saddam Hussein had successfully conspired to evade the UN inspectors and had acquired (or retained) weapons of mass destruction and was perhaps on the way (via the acquisition of

\footnotetext{
${ }^{28}$ The Prime Minister: [...] Secondly, to my hon. Friend, yes, I do support what the President said [that Iraq has aided, trained and harboured terrorists, including operatives of al-Qaeda]. Do not be in any doubt at all-Iraq has been supporting terrorist groups. Hansard 18/3/03.
} 
yellowcake from Niger) to gaining a nuclear capability, thus making the regime a clear and present danger both to the UK and the US ${ }^{29}$

Thus it was presumably Blair's opinion that these conspiracy theories were not just permissible but rationally required. Blair's suggestion on the $18^{\text {th }}$ of March, 2003 that his 'honorable friend', the MP Lynne Richards should 'not be in any doubt at all' that 'Iraq ha[d] been supporting terrorist groups ${ }^{\prime 30}$ suggests that she would have been making some kind of mistake had she thought otherwise. So what does he mean, and what do the pundits who agree with him mean, when they state or imply that conspiracy theories ought not to be believed? Not that theories that posit conspiracies ought not to be believed, since they themselves are prepared to posit theories of precisely this kind, for instance about the conspiratorial goings-on of alQaeda and other terrorist groups.

Perhaps Blair can be restored to consistency, if we reinterpret 'conspiracy theory' as a theory which posits a conspiracy, but also meets some other condition, $\mathrm{X}$. One suggestion, current in the literature, is that a conspiracy theory is a theory which not only posits a conspiracy but also contradicts the official view, suggesting evil deeds by government officials or government agencies. The idea is that we are rationally required not to believe theories like that. It is all right to believe in conspiracies provided that they are consistent with received opinion, or provided that they don't involve wrong-doing on the part of government officials. (Thus it was wrong to believe that the Gang of Four, were conspiring to persecute innocent Party members before they fell from power, but permissible to believe it afterwards once the Party line had changed. Luckily for China, Deng Xiaoping and his confederates sinned against reason by believing in the conspiracy before it became the official view and acted on that belief by taking steps to frustrate this unbelievable conspiracy!) Is this modified principle any better than its predecessor? Not much.

It is true that one of the conspiracy theories on which British foreign policy relied comes out as believable according to the revised principle. We can believe

\footnotetext{
${ }^{29}$ Prime Minister We are now just four days into this conflict. It is worth restating our central objectives. They are to remove Saddam Hussein from power, and to ensure that IRAQ is disarmed of all chemical, biological and nuclear weapons programs, but in achieving these objectives we have also embraced other considerations ...' Hansard 24/3/05. This, of course presupposes that Saddam had weapons programs worth disarming and that they were sufficiently dangerous to make war a necessity.

${ }^{30}$ Hansard 18/3/03.
} 
without irrationality that the events of $9 / 11$ were due to a conspiracy on the part of al-Qaeda, since al-Qaeda is not a government agency, whilst the theory that al-Qaeda did it, is in fact, the received view. But what about the other two theories?

Here we hit a problem. The revised principle says that we should not believe conspiracy theories which contradict the official view and which posit evil deeds on the part of government personnel. But in Iraq the theory that Saddam was in cahoots with al-Qaeda was both inconsistent with the official view (which proclaimed that Saddam was innocent) and posited evil deeds on the part of the Head of State (since Saddam professed hostility to non-state terrorism). Thus in Iraq it was a conspiracy theory in the revised sense. Not so in Britain, because in Britain this theory was the official view and because the theory itself had nothing much to say about the actions of the British Government (of which Saddam was not a member). Thus it was permissible to believe the theory in Britain but rationally wrong to believe it in Iraq. The same goes for the third conspiracy theory on which Blair's policy rested - that Saddam had successfully conspired to acquire WMDs. In London it was believable but in Baghdad it was not. An epistemic principle which forbids a theory in Baghdad but allows it in London leaves something to be desired, but at least it saves Blair from the threat of pragmatic inconsistency since as a London resident, he was rationally entitled to believe the theories on which his foreign policy depended.

Nevertheless the revised strategy would be an intellectual and political disaster if put into practice. Suppose we reinterpret 'conspiracy theory' along the lines suggested. The conventional wisdom metamorphoses into the claim that we should not believe or investigate conspiracy theories involving evil plots by government agents if this contradicts official opinion. But this can be given a relativistic or an absolute reading: either that you should not believe theories which depict evil conspiracies involving your own government which are inconsistent with the official view in your own country, or that that you should not believe theories which depict evil conspiracies involving any government and which are inconsistent with the official opinion anywhere.

On the relativistic reading, this principle permits some people to believe theories that it forbids to others, though those who are forbidden to believe may have better evidence for the theory than those who are allowed to accept it. For what it effectively means is that you are not allowed to believe in evil conspiracies perpetrated by associates of your own government but only in evil conspiracies 
perpetrated by other governments elsewhere. We must be local skeptics even though we are allowed to be international believers. If people all around you are being disappeared by Death Squads and you are tempted (despite the President's denials) to suspect government complicity, the revised epistemic principle insists that you resist this temptation, even though people on the other side of the world, who don't have access to your evidence, are quite at liberty to believe it! The strategy might not be historically disastrous, since you would be allowed to believe in conspiracy theories about the dark doings of previous governments, so long as they were consistent with the official view. But in many countries it would render current events unintelligible, since in many countries evil conspiracies on the part of government members dominate the political scene. (This is par for the course in authoritarian and totalitarian societies and is not unknown even in countries which approximate democracy.) And in rendering the populace politically blind the strategy would render them politically impotent. You can't even begin to solve a problem if you have to shut your eyes to its existence.

The absolute version of this strategy would be slightly less bizarre but even more catastrophic. It would be less bizarre since what is rational to believe would not vary from place to place. But it would be more catastrophic since it would debar us from believing in evil conspiracies on the part of governments anywhere, if those theories were inconsistent with some official view. Bad news for Amnesty International, bad news for their clients the world over as they are imprisoned, beaten, murdered and tortured, since you can't write letters on behalf of people whose problems you are not allowed to believe in.

But I need not spill any more ink denouncing a strategy that nobody seriously advocates. For the concept of a conspiracy theory as it is commonly employed is clearly a chauvinist construct. It is not to be understood in terms of governments generally, but in terms of Western governments, and recent Western governments at that. When people say or imply that conspiracy theories ought not to be believed, they don't just mean that we should not believe theories that postulate conspiracies. Nor do they mean that we should not believe theories which run counter to some official view and which posit evil schemes on the part of some government or other. For they themselves are often eager to trumpet such theories. (Witness Blair and Bush, both officially conspiracy-skeptics, who based, or claimed to base, their foreign policies on the three conspiracy theories listed above.) What they actually mean (in so far as they have a coherent idea) is that we should not believe theories that 
postulate evil schemes on the part of recent or contemporary Western governments (or government agencies) and which run counter to the current orthodoxy in the relevant Western countries. (This still allows a distressing degree of relativism. In Europe, as of 2005 or 2006, you could believe that American agents kidnapped terrorism suspects with a view to having them tortured in foreign parts, since that was consistent with received opinion, but in America it was wrong to do so, since the 'torture' bit of this story was officially played down or denied.) Thus you can believe that Saddam had successfully conspired to acquire nuclear weapons since the chief conspirator in this particular drama was not a member of a Western government. And you can believe that members of the Reagan administration conspired to evade the Boland Amendment by selling arms to Iran to finance the Contras, since the existence of this conspiracy is currently consistent with official opinion. But you must not believe that Bush considered bombing al-Jazeera (let alone that the earlier bombings of al-Jazeera offices were intentional) for that theory involves evil schemes on the part of a recent Western leader and contradicts the official view, which is that this allegation is 'outlandish' (BBC News 22/11/05). Thus we can restore Bush and Blair to pragmatic consistency (along with their allies in the punditocracy) by giving a chauvinistic reading to the concept of a conspiracy theory. In effect, the strategy they suggest is that of not believing and not investigating theories which posit evil schemes on the part of Western governments or Western government agents and which contradict official opinion as it is currently understood. Their conspiracy theories are not like this.

Is this a sensible belief-forming strategy? Obviously not. An epistemic strategy should maximize the chances of truth and minimize the chances of error. But if this strategy had been pursued in the past, many politically important truths would never have come to light. A hypothesis counts as a conspiracy theory in this sense if it a) postulates evil schemes on the part of government members and b) is inconsistent with the official view (where the governments in question are Western governments). Thus there are many theories which are not conspiracy theories now, though they were conspiracy theories in the past: the theory that the Kennedy administration conspired to overthrow Diem, the theory that CREEP conspired to burglarize the Democratic headquarters in the Watergate building and that Nixon conspired to cover it up; the theory that Nixon conspired with the Mob to have peaceniks beaten up; the theory that Nixon and Kissinger conspired to overthrow Allende and connived at the subsequent murders and brutalities; the theory that 
members of the Reagan administration conspired to sell arms Iran in order to fund the Contras; and the theory that suspected terrorists were kidnapped and tortured at the behest of the Bush administration ${ }^{31}$ - all these theories were once inconsistent with official opinion, though nowadays official opinion has managed to catch up with the facts (except perhaps in America where official opinion is still a bit iffy about 'extraordinary rendition', though it is widely accepted elsewhere). Thus it would have been an epistemic mistake to have adopted this strategy in the past. More importantly, it would have been a political mistake. If these activities had gone unnoticed, there would have been no check on the abuse of Presidential power, which would probably have gone on to worse excesses. The price of liberty is eternal vigilance. The revised strategy would have sent us to sleep.

Thus the conventional wisdom has proved to be unwise. On any of the readings of 'conspiracy theory' that I have been able to come up with, it is not the case that we should neither believe nor investigate conspiracy theories. If you wish to vindicate the conventional wisdom, you must do two things. First you must give an interpretation of the term 'conspiracy theory' with roughly the right extension. (Most of the theories castigated as conspiracy theories must qualify as such, and most of the conspiracy-postulating theories that conspiracy skeptics believe in must not.) You must then show that on this interpretation, the strategy of neither investigating nor believing conspiracy theories makes epistemic sense. Until this is done, the idea that conspiracy theories as such are intellectually suspect is a superstition that can be safely dismissed.

\section{6) Victory by Definition? The Case of David Aaronovitch}

That is roughly where I left things in 2007 when I finished the first version of this paper. But since then, an apologist for the conventional wisdom has arisen who has managed to come up with a definition that does indeed make it irrational to believe in conspiracy theories - at least as defined by him. But his definition has an unfortunate consequence. It turns out that many of his paradigm conspiracy theories are not really conspiracy theories in his sense of the term.

In his recent book Voodoo Histories, David Aaronovitch, begins by admitting that 'if a conspiracy is defined as two or more people getting together to plot an

\footnotetext{
${ }^{31}$ I trust nobody objects to this litany of American examples. It is just that I am well acquainted with recent American history (which is of peculiar importance to the world) but am less so with that of other countries. I suspect that similarly discreditable tales could be told about other Western democracies.
} 
illegal, secret or immoral action then we can all agree that there are plenty of conspiracies'. And, of course, if a conspiracy theory is defined as theory that posits a conspiracy then 'we can all agree' that plenty of conspiracies are true, and hence rationally believable. Since he does not care for this conclusion, Aaronovitch redefines the notion of a conspiracy theory. For him 'a better definition of a conspiracy theory might be the attribution of deliberate agency to something that is more likely to be accidental or unintended ... the attribution of secret action to one party that might more reasonably be explained as the less covert and less complicated action of another. So a conspiracy theory is the unnecessary assumption of conspiracy where other explanations are more plausible ${ }^{32}$. This definition is a little lacking in conceptual crispness, but, simplifying somewhat, it boils down to this: a conspiracy theory is a theory which explains some events as due to a conspiracy when it is not reasonable to suppose that they are really due to a conspiracy. In other words it as theory which employs a conspiracy to explain events which are best explained by non-conspiratorial causes. Call a theory which posits a conspiracy a simple conspiracy theory, and a conspiracy theory in Aronovitch's sense an A1-conspiracy theory. (The 'A', of course, stands for Aaronovitch: as for the ' 1 ', we will get to it by and by.) Obviously all A1-conspiracy theories are simple conspiracy theories but not all simple conspiracies are A1conspiracy theories. Aaronovitch himself admits as much when he concedes that 'we can all agree that there are plenty of conspiracies' and hence, presumably, that there are plenty of simple conspiracy theories that it is rational to believe. Thus it is sometimes rational to believe in simple conspiracy theories though it is never rational to believe in A1-conspiracy theories. For Aaronovitch defines them (in part) as conspiracy theories that it is not rational to believe.

But odd at it may seem, many of the conspiracy theories discussed in Aaronovitch's book fail to comply with his own definition, a fact of which he seems to be oblivious. This is not because it is reasonable to believe them (since I agree with Aaronovitch that most of them are false), but because the events in question are best explained by rival conspiracies - a point that Aaronovitch himself is at pains to prove. The reason it is irrational to believe these theories is not that the events that they explain were not caused by conspiracies - the reason it is irrational to believe them is that the events that they explain were caused by different conspiracies. Thus we are not choosing between conspiracies and contingencies but between one conspiracy

\footnotetext{
${ }^{32}$ Aaronvitch (2011)
} 
theory and another. But according to Aaronovitch's slanted definition, a theory only counts as A1-conspiracy theory if it explains some events as due to a conspiracy when they ought to be explained by non-conspiratorial causes. But this entails that many of the theories that he discusses do not count as conspiracy theories in the sense that he defines.

Consider, for example, the case of the Zinoviev Letter, which Aaronovitch discusses in the Introduction. This was a forged communication, allegedly from Grigori Zinoviev, whose publication in the Daily Mail supposedly scuppered the reelection of Ramsay McDonald's Labour Government in 1924 by suggesting that the Labour Party was unduly close to the Bolsheviks. Here the fact to be explained is the publication of the Zinoviev Letter. There are two explanations, one false the other true. The false explanation is that the letter was forged by MI6 and leaked by highranking intelligence officers who wanted to bring Labour down. The true explanation is that the Letter was concocted by a group of White Russian antiCommunists operating out of Latvia, who wanted to sabotage the recent treaties between Britain and the young Soviet Union; that the Letter was passed on to MI6; and that it was leaked to the Daily Mail by junior intelligence officers who wanted to bring Labour down. Both theories explain the Letter as due in part to a conspiracy (one of them to two conspiracies) and both therefore are conspiracy theories in the simple sense of the term. The reason why it is not reasonable to accept the first theory is not because the Letter wrote itself or because it somehow leaked itself to the Daily Mail (which is what would have been required for there to be no conspiracy) but because it is reasonable to believe the alternative conspiracy theory which is based on the careful research of the historian Gill Bennett. Or consider the Protocols of the Elders of Zion, featured in Chapter 1. Here the fact to be explained is the publication of the Protocols. There are two explanations, one false the other true. The false explanation is that the Protocols were the genuine transcripts of a meeting of influential Jews, recording their wicked schemes to take over the world, transcripts which had somehow found their way into the public domain. The true explanation is that they were concocted by a group of Tsarist anti-semites associated with the Okhrana, and that they were disseminated with a view to fostering anti-semitic sentiment (in which endeavor they were a horrific success). Both theories explain the Protocols as due, in part, to a conspiracy and both are therefore conspiracy theories in the simple sense of the term. The reason why it is not reasonable to accept the first theory is not because the Protocols forged themselves (or because they were the 
products of a 'lone forger') but because it is reasonable to believe the alternative conspiracy theory that they were forged and disseminated by a bunch of anti-semitic conspirators. Or consider the Moscow Show Trials and, in particular, the Trial of the Anti-Soviet Trotskyite Center (aka the Trial of the Seventeen), starring Pyatakov and Radek as the chief defendants, which is the theme of Chapter 2. Here what needs to be explained is the trial itself and the abject confessions of the star defendants. Here again there are two explanations, one false and the other true. The false theory is that Radek and Pyatakov really were at the head of a massive conspiracy of spies, saboteurs and wreckers which had mercifully been detected by the vigilance of the NKVD. The true theory is that they were the victims of a massive conspiracy to frame and defame those Old Bolsheviks who might perhaps have posed a threat to Stalin, and that the false confessions were extracted by bullying, torture, threats and lying promises ${ }^{33}$. The reason why it is not reasonable to accept the first theory is not because the defendants spontaneously decided to confess to non-existent crimes, but because it is reasonable to believe the alternative conspiracy theory that they were the victims of a massive and murderous frame-up. Of course, the conspiracy theory that really exercises Aaronvitch is the theory of the 9/11 Truthers that the Twin Towers and WTC 7 fell as a result of controlled demolition perpetrated by persons unknown (but presumably associated with the US Government). Here what needs to be explained is the collapse of the buildings. And here again there are at least two explanations, one supposedly false and the other true. The false theory is that the Towers did not fall because they were hit by planes and that WTC 7 did not fall because of flaming office furnishings, but that all three fell because of explosive charges laid in advance and timed to go off after the planes hit. Truthers don't necessarily deny that the planes were hijacked by a conspiracy of al-Qaeda operatives, but they usually suggest that people associated with the Government connived at their schemes, allowing them to proceed unhindered. The true theory (in Aaronovitch's opinion) is that the successful al-Qaeda conspiracy to hijack the planes and crash them into the Towers suffices to explain the catastrophe. The reason why it is not reasonable to accept the first theory (if indeed it is not reasonable) is not because these massive buildings collapsed because of structural defects or because a bunch of bored passengers spontaneously decided to hijack the planes and ram them into Twin Towers for a suicidal lark, but because it is

\footnotetext{
${ }^{33}$ However we should not waste too much sympathy on the defendants, given Pyatakov's role in the Trial of the Social Revolutionaries fifteen years earlier and Radek's readiness, even when not under much pressure, to betray his former comrades such as Blyumkin.
} 
reasonable to believe the alternative conspiracy theory, namely that al-Qaeda did it. Aaronovitch defines a conspiracy theory as a theory which explains some events as due to a conspiracy when it is not reasonable to suppose that they are really due to a conspiracy. But if we accept this definition, it follows that that none of the theories that I have listed should count as conspiracy theories. For though the theories themselves may be false, there is good reason to suppose not that the events in question were due to non-conspiratorial causes, but that they were actually caused by some other conspiracy.

Here's a logical parallel. Suppose you want to uphold the thesis that all Muslims are terrorists. Unfortunately if 'Muslim' is defined in the ordinary way as a believer in Islam, then 'we can all agree' that there are millions of Muslims who are not terrorists - indeed, we must agree to this on pain of obvious falsehood. No worries. You simply redefine a 'Muslim' as a believer in Islam who is also terrorist. This guarantees the truth of 'All Muslims are terrorists' so long as 'Muslim' is understood in this modified sense. However, in a sudden rush of blood to the head, you add to your definition a further clause which states that nobody counts as a Muslim unless he is also beardless. Thus to say that somebody is a Muslim according to this new definition is to say that he is a beardless terrorist who subscribes to Islam. But his means that many of your paradigms of Islamic terrorism such Osama Bin Laden and Ayman al-Zawahiri no longer qualify as Muslims according to your revised definition, since both sported spectacular beards. From a logical point of view Aaronovitch's tactics are no better than this, though morally speaking, they are a lot less obnoxious.

Now the reason I bang on about this not just to make fun of Aaronvitch's logical shortcomings (after all, the poor fellow is only a leading columnist for The Times, so perhaps he can't be expected to know any better) but because his examples raise a serious issue. The general drift of the conventional wisdom is to trash conspiracy theories as due to a defective style of thinking. People tend to get it wrong because they have an irrational tendency to posit conspiracies where there are no conspiracies. We then get a good deal of sneering, disguised as dispassionate diagnosis, of why people are prone to this intellectual malaise. But if some conspiracy theories are rational and if the rational alternative to a false conspiracy is often not a no-conspiracy theory but a true conspiracy theory, then this isn't going to wash. People don't just believe in conspiracy theories because they are prone to some syndrome of conspiracy-thinking - they often believe them because the theories 
themselves are rational and even correct, and even when the theories are not, people may well believe in them because, for whatever reason, they have pitched upon the wrong conspiracy. The idea that there is an irrational syndrome which provides a general explanation of why people subscribe to conspiracy theories is a diagnosis in search of a disease, or, more properly, a shoddy ad hominem disguised as a diagnosis.

Can we extricate Aaronovitch from the logical hole that he has managed to dig for himself? His project was to construct a definition to underwrite his evident belief that conspiracy theories are somehow irrational. The problem is that the definition he constructs excludes some of his own paradigms, implying that despite their obviously conspiratorial character, the theories in question aren't conspiracy theories after all. Let's fix the problem before evaluating the project. Instead of defining a conspiracy theory as 'the unnecessary assumption of conspiracy where other explanations are more plausible' he should define it as 'the unnecessary assumption of a particular conspiracy where other explanations - including explanations involving conspiracies - are more plausible'. Thus a conspiracy theory becomes a theory which explains some events as due to a conspiracy when it is not reasonable to suppose that they are due to that conspiracy. Or in other words, a conspiracy theory is a simple conspiracy theory that it is irrational to believe. Call conspiracy theories in this sense A2 conspiracy theories, since we are modifying Aaronovitch's original definition. Then we have what might be called the Aaronvitch thesis, namely that that it is irrational to believe A2 conspiracy theories, or in other words that it is irrational to believe conspiracy theories that it is irrational to believe. As Horatio said when confronted with a similar tautology, "There needs no ghost, my lord, come from the grave/To tell us this ${ }^{34}$ - nor for that matter a popular history book by Aaronovitch full of interesting examples that are slightly beside the point. To return to our parallel, it is as if somebody tried to uphold the claim that all Muslims are terrorists by redefining 'Muslim' as a believer in Islam who is also terrorist, but this time without adding that dreadful faux pas about not having a beard.

Does this definition provide any support the conventional wisdom that conspiracy theories are irrational and ought not to be believed? In one sense no, but in another sense yes. Let us distinguish between the CW or Conventional Wisdom thesis that it is (always or usually) irrational to believe conspiracy theories and the Aaronovitch thesis that it is irrational to believe A2 conspiracy theories, or in other

\footnotetext{
${ }^{34}$ Shakespeare, Hamlet, I.iv.
} 
words that it irrational to believe conspiracy theories that it is irrational to believe. Unless the CW thesis is to be interpreted as tautological, the first is contingent and the second analytic. Thus the first does not follow from the second, since you cannot derive contingencies from analytic truths. The point becomes clear once we realize that the Aaronvitch thesis is quite compatible with the negation of the $\mathrm{CW}$ thesis. Even the most paranoid conspiracy theorist - the kind of person who wears a tin foil hat to prevent the evil Martians from messing with his brains - can cheerfully accept that it is irrational to believe conspiracy theories that it is irrational believe whilst vehemently insisting that there are many conspiracy theories that it is rational to believe. Since the negation of the $\mathrm{CW}$ thesis is compatible with the Aaronovitch thesis, you can't derive the one from the other. And since the Aaronovitch thesis is an empty tautology, it does not make the CW thesis the least bit more likely. You can't derive the conclusion that a thesis is probable from a premise that is entirely analytic. Thus Aaronvitch's definition provides no rational argument for the conventional wisdom. At least it can only do so if the CW thesis itself is converted into an empty tautology, in which 'conspiracy theory' is defined as conspiracy theory that it is not rational to believe. Thus if the pundits of the conventional wisdom don't want to be trumpeting a tautology they had best reject his definition. For it provides no support for any substantive claim.

No rational support perhaps - but this is not to say that it cannot be rhetorically useful. Suppose you are an aspiring pundit trying to make a name for yourself in the mainstream media by doing down inconvenient conspiracy theories. You can score a sequence of dialectical victories by using one definition to defend the conventional wisdom and another to attack your opponents. Suppose that you are defending the $\mathrm{CW}$ thesis that it is irrational to believe in conspiracy theories, and some tiresome pedant points out that that there are many conspiracy theories have been proved beyond all reasonable doubt. You can cheerfully concede the point, helpfully explaining that by 'conspiracy theory' you mean, inter alia, a theory that it is not rational to believe, and that, though the theories in question are eminently believable, in your book, at least, they don't count as conspiracy theories. All you meant to say when defending the CW thesis was that it not rational to believe irrational conspiracy theories, and surely, friends, we can all agree on that? (Of course you had better not put it quite as bluntly as that or the subterfuge will be too obvious.) Then, when that pedant has gone away, you can argue against the next conspiracy theorist that comes along, a) that since their theory posits a conspiracy it 
is therefore a conspiracy theory, and b) that since, by the CW thesis, it is irrational to believe in conspiracy theories, it follows that theirs is a theory that it is irrational to believe. The beauty of this procedure is that there is no need to discuss the merits of the theory. No need to address the evidence, no need to discuss delicate considerations of plausibility that might be embarrassing to the powers that be! The fact that it is a conspiracy theory suffices to damn it. Thus Aaronovitch's definition tends to grease a fallacious slide from ' $X$ is a theory which posits a conspiracy' via ' $X$ is a conspiracy theory' to the conclusion that ' $X$ is irrational (and ought not to be investigated or believed)'. This is a style of argument that cannot be validated by adding an intervening premise that is both true and non-tautologous. (And even if you did add the tautologous premise, it still wouldn't be any help.) It lends aid and comfort to sophistical politicians such as Tony Blair, leaving theories that deserve to be investigated in a limbo of supposed irrationality. It may be that Aaronovitch would not mind about this since he is rather more tolerant of Tony Blair than I am inclined to be. But then, when it comes to detecting sophistries whether his own or other peoples', Aaronovitch is not a man to be relied on. 


\section{References}

Aaronovitch, David (2011) Voodoo Histories, Kindle edition, Vintage Digital.

Baehr, Peter ed. (2000) The Portable Hannah Arendt, Harmondsworth, Penguin.

BBC News, Tuesday, 22 November (2005)

http: / / news.bbc.co.uk/2/hi/uk_news/politics / 4459296.stm

Blair, Tony (2010) A Journey, London, Hutchinson.

Burke, Edmund (1992) Further Reflections on the Revolution in France, ed. Ritchie, Indianapolis, Liberty Fund.

Carrol, Lewis (1871) Through the Looking-Glass, and What Alice Found There, Adelaide etext version, http: / / etext.library.adelaide.edu.au/c/carroll_1/looking / looking, html

Chang, Jung and Halliday, Jon. (2005) Mao: the Unknown Story, London, Jonathan Cape

Coady, David ed. (2006a) Conspiracy Theories: the Philosophical Debate, London, Ashgate.

Coady, David ed. (2006b) ‘Conspiracy Theories and Official Stories’ in Coady (2006a), pp. 115-128

Coady, David (2007) 'Are Conspiracy Theories Irrational?' Episteme: A Journal of social Epistemology, 4;2, pp 193-204.

Fenby, Jonathan. (2003) Generalissimo; Chiang Kai-Shek and the China he Lost, London, Free Press

Husting, Ginna and Orr, Martin. (2007) 'Dangerous Machinery: "Conspiracy Theorist" as a Transpersonal Strategy of Exclusion', Symbolic Interaction, Vol. 30, No. 2, Pages 127-150.

Keeley Brian L. (1999) 'Of Conspiracy Theories' The Journal of Philosophy, 96 (3): 109-126, reprinted in Coady ed. (2006) pp. $45-60$

Machiavelli, Niccolo (2005) The Prince, trans Bondanella, Oxford, Oxford University Press.

Mackie, J.L. 1981. The Miracle of Theism, Oxford, Oxford University Press, pp. 200-203.

Mortimer, Ian (2010) 1415: Henry V's Year of Glory, London, Vintage.

Musgrave, Alan (2010) Secualr Sermons, 
Pigden, Charles (1990) 'Ought-Implies-Can: Luther, Erasmus and R.M. Hare', Sophia, vol 29, no.1 pp. $2-30$

Pigden, Charles, 'Popper Revisited or What is Wrong With Conspiracy Theories?' The Philosophy of the Social Sciences, vol. 25, no. 1. pp. 3-34. (1995)

Pigden, Charles (2006a) 'Popper Revisited or What is Wrong With Conspiracy Theories?' ch. 3 of Coady, David ed. Conspiracy Theories: the Philosophical Debate, London, Ashgate, 2006, pp. 17-47 (slightly revised version of Pigden (1995)).

Pigden, Charles (2006b) 'Complots of Mischief' ch. 12 of Coady, David ed. Conspiracy Theories: the Philosophical Debate, Aldershot, Ashgate, pp. 139-166.

Pigden, Charles (2007) 'Conspiracy Theories and the Conventional Wisdom' (2007) Episteme: A Journal of social Epistemology, 4;2, pp 193-204

Pigden, Charles (2010) 'On the Triviality of Hume's Law: a Reply to Gerhard Schurz' in Pigden, Charles R ed. Hume on 'Is' and 'Ought', Houndmills, Palgrave, Macmillan, pp 217-238

Shawcross, William. 1986. Sideshow: Kissinger, Nixon and the Destruction of Cambodia, London, Hogarth Press.

Smith, Adam. 1981. An Inquiry into the Causes of the Wealth of Nations, vol. 1, edited by Campbell, Skinner and Todd, Indianapolis, Liberty Fund.

Summers, Anthony. 2000. The Arrogance of Power: the Secret World of Richard Nixon, London, Gollancz. 


\section{Academic Biography}

Charles Pigden is associate professor of philosophy at the University of Otago, New Zealand and is the editor of Russell on Ethics (1999) Hume on Motivation and Virtue (2009) and Hume on Is and Ought (2001). He has published on abstract objects, the analytic/synthetic distinction, negative facts, conspiracy theories, coercive theories of meaning, the Milgram experiments, the Is/Ought Problem and the History of New Zealand Philosophy and has as articles on Moore, Geach, Russell, Hume, Nietzsche, Mackie, Anscombe, Derrida and Dostoyevsky. However, if pressed, he will admit to being a meta-ethicist. 